\section{RECENT WORK OF THE INDIAN MARINE} $S U R^{\prime} V E Y{ }^{1}$

THE importance of the work intrusted to the Indian Marine Survey, alike from the point of view of the hydrographer of the geologist, and of the zoologist, is so well known to all men of science that it would be mere waste of time to attempt to emphasise it on the present occasion. All the Reports that have from time to time been published by this Survey bear witness to the zeal and energy with which the work is carried onfrequently under circumstances of great difficulty-and $t o$ the capacity and accomplishments of the officers to whom it is entrusted. But it will be no reflection on previous documents of the same nature if we call attention to the special interest attaching to the one now before us, on ascount of the varied nature of the subjects on which it touches, the philosophical manner in which these are treated, and the problems presented by many of them.

The first section of the Report is by Commander T. H. Heming, R.N., who has entire charge of the Survey; and geologists will read with great interest his account of the rapid silting-up of the Gulf of Martaban that is now in progress. It appears that an enormous quantity of sediment is being carried into the Gulf by the Salween River; a sample of water taken at spring tide during the dry season yielding no less than $1 / 300$ th of dry mud by weight. The deposit has mainly taken place outside the 10-fathom line, and so heavy is it that in spots where there were formerly from 40 to 50 fathoms, the depth is now reduced to from 15 to 20 ; the area affected being approximately 2000 square miles. "Putting the amount of water discharged loy the river flowing into the Gulf at a low estimate," say's the Report, " and supposing it capable of supporting on the average one-quarter of the proportion of sediment held in solution [? sucpension] by the specimen examined, there would be more than enough solid matter carried into the Gulf in forty years to cause the silting-up) which has actually taken place."

Another point of interest in this section is the longitude of the Andamans, which, as deduced by running a meridian distance to Sugar-loaf Island, was found to differ by I' $70^{\prime \prime}$ from that given by the Great Trigonometrical Survey. In consequence of this discrepancy it is now proposed to run a meridian distance between Port Blair and Diamond Island both ways, in order to obtain the best possible results with the means at disposal.

Passing on to the section of the Report written by the Surgeon-Naturalist, Captain A. R. S. Anderson, we may call attention to the remark as to the rapid change in the coloration and appearance of the animals of Ford Bay, Great Cocos Island, when the coral bottom of the open channel is left for the sandy bottom of the bay. While quarantined off Colombo a lucky haul brought up no less than forty-one examples of the rare crustacean Lupocyclus orientalis, of which only three specimens were previously known to science. In another haul, which brought up a miscellaneous collection of dead corals, sharks' teeth, fish-bones and bones of turtles, the interesting fact was discovered that while some of these were in practically the same condition as at the time of their deposition, others had been highly impregnated with mineral matter. No enbedding in sediment had, however, preceded the fossilisation (if the term is permissible in this connection), which had evidently taken place as the bones lay loose on the sea-bottom.

In a haul taken some distance east of the Maldives, Captain Anderson was fortunate enough to procure over 200 specimens of an echinoderm nearly related to the West Indian Palaeoprezestes hystrix, but apparently specifically distinct. When. placed in spirit these urchins turned it a magnificent rich purple, although their own colour was a dull madder.brown. Many other rare and interesting invertebrates were obtained at other dredging stations, but we must omit mention of any of these to refer to a totally different sulject.

Between Colombo and Rangoon an excellent opportunity was afforded of carefully observing the flight of the common flying. fish (Exococtus erolans). "When they first rise from the water," writes the narrator, "they do so with a very rapid fluttering of their wings lasting for two to three seconds; they then soar along till their speed is so reduced that they descend and touch the water, into which they either fall with a splash or dip the elongated tip of the caudal fin, and, I think, the ventral fins on which they seem to poise themselves, again rapidly

1 Administration Report of the Marine Survey of India for the Official Year $1898-99$. Pp. 17. (Bombay : Government Central Press, 1900.) NO. 1635 , vol. 63$]$ vibrate their wings, and get up sufficient speed to renew their flight; this proce is I have seen them repeat as often as seven times in the course of one long flight. Very occasionally, however, I have observed these fish fluttering their wings without touching the water with their caudal and ventral fins.

After mentioning that in order to observe these motions calm weather and a binocular are necessary, Captain Anderson pro. ceeds to say that he fails to understand how Moseley, as narrated in his "Naturalist on the Challentger," as well as several other observers, have denied the fluttering of the wings in flying-fish. Apparently he is unaware that it has been stated in the "Ruval Natural IIistory" by the editor, as the result of personal observation, that these fish do possess the power in question, as indeed had been attested in Land and Wuter by a much earlier observer. Captain Anderson's observations also corroborate the statement made by the writer last referred to, that flying-fish are capable of altering the direction of their flight : an attribute that was denied to them by Dr. Möbius in his well-known account.

In a later paragraph Captain Anderson draws attention to the circumstance that in flying-fish the lower surface of the body is flattened in order to enable them the more easily to rise from and hover over the water, and that in the allied genus, Hemirhaniphus, ${ }^{1}$ the members of which rush at full speed along the top of the water with only the hinder portion of the body immersed, a similar flattening is observable.

While lying in Burmese waters off Moulmein, the surveying vessel encountered a large quantity of drift-wood brought down by the Moulmein river. Some of this became entangled in the paddle-wheels, and on three mornings snakes were found on the floats. A female leopard, probably carried down by the strong tide, took refuge one morning on a cargo boat moored somewhat higher up, and eventually swam ashore, where she was shot. These instances are of much interest in connection with the dispersal of species.

Much of the latter portion of this section of the Report is occupied by an account of the author's experiences in the Andaman Islands, where he has much to say concerning both the natives and the fauna. In one passage he mentions that, while walking through the forest, a native announced the presence of a large mass of wild honey in the immediate neighbourhood, which he detected by its smell, although this was quite imperceptible to the European members of the party.

In conclusion, Captain Anderson refers to the remarkable circumstance that in the neighbourhood of the Andamans there occur masses of sandstone at a depth of between 39 and 226 fathoms which are quite bare of coral, although there is an abundant growth of the same in the immediate neighbourhood. It is inferred that the bare area, and probably also the larger portion of the bank, has never been within the zone of massive reef-building corals. "I Had it ever been so, it is most improb. able that there should be bare rock exposed at 39 fathoms. For that the bank is eminently suitable for the growth of coral, both the dredgings and the soundings, by bringing up live coral, showed; at no part of the bank was there any turbidity of the water sufficient to check coral-growth. . . . Were the theory correct that, given a bank rising within a comparatively short distance of the surface, deposit will accumulate on that bank and so form a basis for a coral island, there is no reason why, in the case of this bank, bare rock without any such deposit on it should be found."

Many other equally interesting and suggestive extracts might be culled from this valuable report did limitations of space permit.

R. L.

\section{THE TEACHING OF PHYSIOLOGY.}

$\mathrm{I} T$ is scarcely too much to say that the only real scientific knowledge is that obtained through personal experience. Lectures and text-books have their places in a scheme of instruc. tion in science, but they only convey information at secondhand, whereas original experimental work creates and fosters the inquiring spirit characteristic of a progressive mind. What students need to be taught is that they must be not so much receptive as constructive; and the way to give force to this view is to insist upon their taking an active share in investigation at

1 A mis-spelling of this and several other names is noticeable in the Report, but, as the writer of this notice is well aware, much allowance must be made for an author whose copy is set up by native Indian printers. 